$\angle$ Research Square

\title{
Comparative Parameters Evaluation of Internal Combustion Engines Naturally Aspired and Supercharged With Hybrid Turbocharger
}

Chiriac Rares ( $\square$ rares-lucian.chiriac@unitbv.ro )

Universitatea Transilvania din Brasov https://orcid.org/0000-0002-2226-7107

Anghel Chiru

Universitatea Transilvania din Brasov

\section{Original Article}

Keywords: internal combustion engines, hybrid turbocharger, electric generator, green energy, AMESim Software

Posted Date: June 9th, 2020

DOl: https://doi.org/10.21203/rs.3.rs-32684/v1

License: (c) (i) This work is licensed under a Creative Commons Attribution 4.0 International License.

Read Full License 


\section{Abstract}

Internal combustion engines have an operating efficiency that can be exploited to increase their performance. Some of the waste gases can be recovered through technical solutions such as turbocharging. The turbocharging solution is one of the most popular technical solutions for increasing the energy performance of internal combustion engines. This requires an analysis of the energy balance of the internal combustion engine. This shows that there is a significant reserve of energy in the exhaust gases, which can be used to increase the engine efficiency. One solution is to use this energy to drive a turbine coupled with an electric generator. This article aims to present the result of the experimental research of the hybrid turbocharger, simulating and validating the new solutions for increasing the energy performance of internal combustion engines through hybrid turbochargers using a coupled electric generator. The simulations will be performed using AMESim software developed by Siemens to demonstrate through calculations the efficiency of new solutions, such as a hybrid turbocharger. The tests will be performed using an diesel internal combustion engine with a cylinder capacity of 1.9 liters which is also simulated with AMESim software. The residual exhaust gases of the internal combustion engine will drive the hybrid turbocharger turbine and generate electricity. Electricity can then be used for storage in the car battery or for consumption by the car's electrical system. The article also includes a comparative study between the power and torque of the naturally aspirated internal combustion engine equipped with a hybrid turbocharger.

\section{Introduction}

The importance of water-cooled exhaust turbochargers will increase in the near future. Turbochargers are a key component in reducing fuel consumption. [1] The purpose of the turbocharger is to increase the amount of compressed air introduced into the engine cylinders. It can also be used as an engine brake for large trucks with diesel engines. Indeed, the cost and development time must be reduced to meet both customers target and strict emission standards. The current turbocharger simulation codes are largely based on the search tables (airflow and air mass) provided by the manufacturers. [2] In recent years, internal combustion engines have been developed, and expectations have increased, such as performance, pollution in relation to costs, so the research area has also expanded. [3] More energy efficiency and less polluting processes are needed in the internal combustion engine sector. Compression ignition engines are used in electricity generation, marine and transport and the Otto engine is used for transport, but in both cases, processes can be improved and made to allow for higher pressure ratios and also to generate electricity under sufficient operating conditions. [4] One way to improve engine performance is to improve turbocharger performance. In this context, the gas turbocharger plays an important role in future designs, especially to reduce $\mathrm{CO} 2$ emissions. This is caused by the technical complexity of this device and also by the significant influence of the turbocharger performance and fuel consumption of the engine. [5] The turbocharger was essential in the use of low-cylinder engines at high power. As an advantage of engines with lower displacement and fewer cylinders, we can mention both higher efficiency and lower volume. In gasoline car applications, in the past there was a clear trend of 
switching from four-cylinder engines to three-cylinder engines, but there was no definite trend in the diesel engine segment. In off-road applications, the use of three-cylinder diesel engines continues to increase, and even two-cylinder engines are in series production. [6] Due to the heterogeneity of multi-part materials, manufacturing and assembly errors and uneven turbine carbon, a random imbalance can usually develop that will induce excessive rotor vibration and even lead to nonlinear vibrations. [7] For this the compressor-generator coupling manages to eliminate this problem. The influence of shaft quality on the turbine and rotor was not taken into account in the dynamic model analysis process. The rotor of the turbocharger rotor was simplified first, the different parts of the simplified rotor were analyzed and the dynamic model of the rotor was established. [8] The exhaust volume represents the entire volume of ports, manifold and turbine volute. [9] A hybrid turbocharger was built to demonstrate that the turbocharger has a great ability to improve, namely a turbocharger coupled to a speed ratio and an electric generator. (figure 1)

Table 1 contains all the important components of the hybrid turbocharger, such as: turbocharger components, speed ratio (1:10) and the $100 \mathrm{~W}$ electric generator, also with the main symbols used by the simulation with AMESim software.

The main component parts of the turbocharger prototype, such as: turbocharger, speed ratio and electric generator presented directly as components, but also as simulation parts of the AMESim software.

Table 1 contains all the important components of the hybrid turbocharger, such as: turbocharger components, gear ratio (1:10) and the 100W electrical generator, also with the main symbols used by the simulation with AMESim software. 
Tabel 1: The main component parts of turbocharger

prototype such as: turbocharger, gear ratio and

electrical genetator presented as components directly,

but also as simulation parts of AMESim software
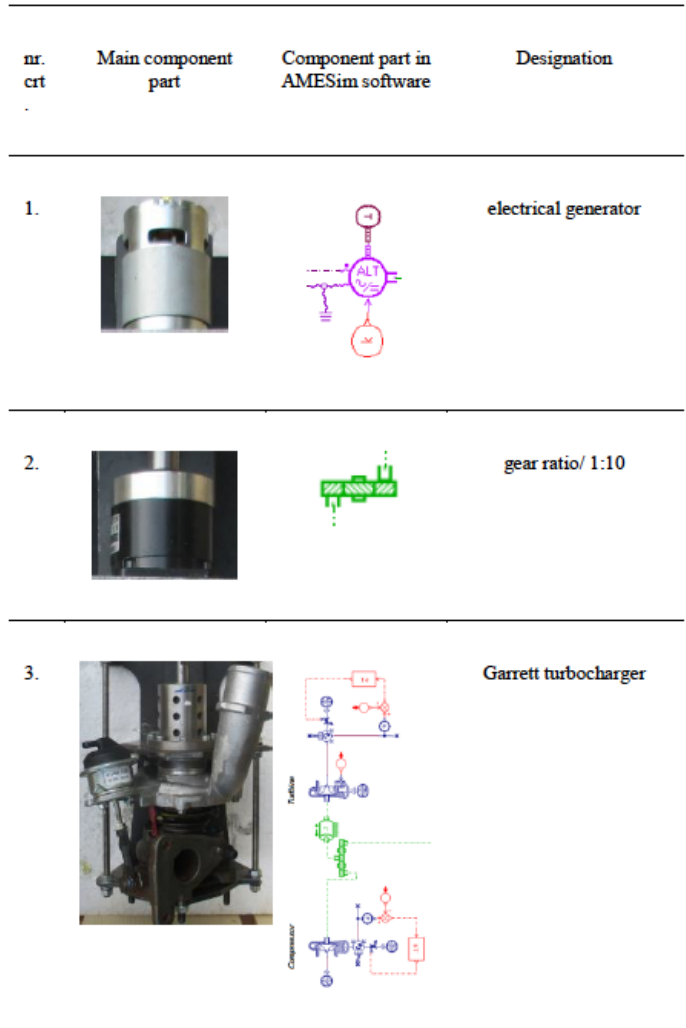

\section{Objetive}

The general objective of this experimental work is to demonstrate that the turbocharger has a very good performance improvement. But to demonstrate this, the simulation and validation results of the hybrid turbocharger prototype must also be presented.

Figure 2 illustrates the overview of the hybrid turbocharger with the main components of the simulation system.

The efficiency of the turbine is influenced by different drives, depending on the number of cylinders. In addition, another influence of the number of cylinders on the pumping losses was found. This effect strongly depends on the exhaust volume before the turbine, which is why the subject of constant pressure and turbo power supply must be examined in detail. It was found that a smaller number of cylinders $(<4)$ has, in principle, higher pumping losses, even with the same turbocharger efficiencies. The lowest pump losses can be obtained with four-cylinder engines. It has also been shown that this problem is completely different for diesel and petrol engines. [10]

The demand for continuous improvement of the transient performance of diesel engines requires a higher pressure and a more efficient turbocharger. [11] 
Also in figure 3 below are presented the components of the engine with internal combustion diesel of cylindrical capacity 1.9 liters naturally aspirated modeled by AMESim software. This is the reference model, then the results of the experimental data will be compared with the model developed by the AMESim software, namely the 1.9 liter cylindrical diesel internal combustion engine equipped with a hybrid turbocharger.

Also in figure 4 below are presented the components of the supercharged 1.9 liter diesel internal combustion engine equipped with a hybrid turbocharger modeled by AMESim software.

\section{Methodology}

The basic equations used for the mathematical simulation of the compressor, turbine and alternator can be divided into two categories namely for the mechanical part and for the electrical part.

\subsection{Equations for the mechanical part}

To take into account the real engine operating conditions, the rotary speed and the mass flow rate values are corrected or reduced.

3.1.2 Compresor equasion, speed/ flow rate

$$
\begin{aligned}
& N_{c o r}=\frac{N_{a c t}}{\sqrt{\frac{T_{u p}}{T_{s t}}}} \\
& N_{r d d}=\frac{N_{a c t}}{\sqrt{T_{u p}}}
\end{aligned}
$$

$$
\begin{gathered}
\dot{m}_{c o r}=\dot{m}_{r e d} \cdot \frac{\sqrt{\frac{T_{u p}}{T_{s t}}}}{\frac{P_{u p}}{P_{s t}}} \\
\dot{m}_{c o r}=\dot{m}_{r e d} \cdot \frac{\sqrt{T_{u p}}}{P_{u p}}
\end{gathered}
$$

$$
P R=\frac{P_{\text {out }}}{P_{u p}} A_{0}=\sqrt{\frac{T_{\text {out }}}{T_{u p}}\left(\frac{1+\frac{\gamma-1}{2} M_{\text {out }}^{2}}{1+\frac{\gamma-1}{2} M_{u p}^{2}}\right)}=
$$

$$
\sqrt{\left\{1+\frac{P R}{\eta}{ }^{\frac{\gamma_{-1}}{\gamma}}-1\right\}}
$$

\subsubsection{Turbine equasions, speed/ flow rate}




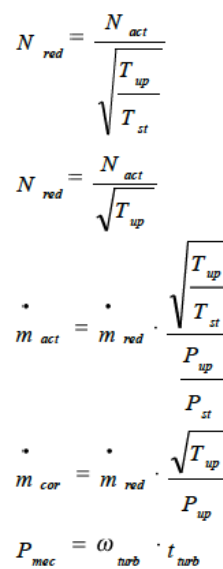

\subsection{Equations for the electrical part}

The main alternator parameter are: rotary velocity in [rev/min], temperature in [degC], current in [A], torque in [Nm], efficiency in [null] (i.e. no unit), losses in [W] (see Figure 5)
$P_{e}=|U \cdot I|$
$I=\frac{U}{R}$

(LMS AMESim, Ameshelp Library)

\section{Results}

The waste gas energy will be transformed with the help of the hybrid turbocharger both in energy that with the compressor will compress air for the engine but also electricity with the help of the electric generator connected to the turbocharger shaft outside.

The results show the electrical parameters resulting from the rotation of the turbocharger, namely: current intensity, voltage and power output. This is the green energy produced by the turbocharger at a constant speed of 162400 revolutions per minute, with a resulting pressure of about 1 bar.

Figure 6 shows the voltage resulting from the electric motor from the experimental research in relation to time. The value of the experimental research value is from 0 to 25 volts. It also illustrates the intensity of the current resulting from the electric motor in the relationship of experimental research with time. The range of experimental research values is between 0 and 5 Amperes. It is also and illustrates the electric power resulting from the electric motor from the relationship of experimental research with time. The value of the experimental research value is from 0 to 100 Watts.

Figure 7 also shows the voltage resulting from the AMESim simulation in relation to the time with the value of the simulation range from 0 to 23 Volts. It also illustrates the current intensity resulting from the AMESim simulation in relation to time, with the simulation value between 0 and 5 Amperes. The electrical 
power resulting from the AMESim simulation is also and is presented in relation to the time with the value of the simulation range from 0 to 115 Watt.

Figure 8 illustrates the rotor shaft with rotational speed per minute and from experimental research in relation to time. The range of experimental research values is from 0 to $162400 \mathrm{rpm}$.

And figure 9 illustrates the rotor speed shaft in rotation per minute, speed simulated with AMESim in relation to the time with the simulation value between 0 and $162400 \mathrm{rpm}$.

Figure 10 illustrates the compressor outlet pressure from the experimental results over time. The range of the experimental working value is from 0 to 1.6 bar.

And figure 11 illustrates the compressor outlet pressure simulated with AMESim in relation to the time with the simulation value between 0 and 1.6 bar.

Figure 12 shows a comparison following the experimental results between the rated natural engine power of maximum $25 \mathrm{~kW}$, hybrid turbo of maximum of maximum $17 \mathrm{~kW}$ and generator power of maximum $0.025 \mathrm{~kW}$ at $100 \%$ load.

Figure 13 shows a comparison between the torque developed by the naturally aspirated engine of maximum $90 \mathrm{Nm}$ and the torque of the engine equipped with hybrid turbo of maximum $100 \mathrm{Nm}$ at $100 \%$ load.

Figure 14 shows the result of the simulation with AMESim software of the nominal power of the 1.9 liter naturally aspirated diesel engine of maximum $23 \mathrm{~kW}$.

Figure 15 shows the moment of maximum $75 \mathrm{Nm}$ simulated with the AMESim software of the naturally aspirated Diesel 1.9 engine at $100 \%$ load.

Figure 16 shows the result of the simulation with the AMESim software of the nominal power of the 1.9 liter diesel engine equipped with a hybrid turbocharger of maximum $18 \mathrm{~kW}$ at $100 \%$ load.

Figure 17 shows the moment simulated with the AMESim software of the Diesel 1.9 engine equipped with a hybrid turbocharger of maximum $75 \mathrm{Nm}$ at $100 \%$ load.

\section{Conclusions}

The new composite turbo systems for the automotive industry to recover the energy of the internal combustion engine have three basic elements: the extended shaft to engage the power generator at the blower end, a gear that reduces the rotation of the turbocharger and a cooling system for the generator that is optional.

Analyzing the values obtained through the experimental part and the simulation part, it can be stated that the turbocharger has a great potential to develop and obtain ecological electricity for the vehicle. 
The hybrid turbocharger can be used with hybrid engines, but also for the classic solution of internal combustion engines.

Parallel sequential turbocharging systems can generate, they are able to operate in different ways, to generate electricity for the vehicle's electric motor both for consumption and to be stored in batteries. [14]

The main advantages of the new hybrid turbocharger are: the consumption of green electricity and storage in the main battery of the vehicle, it also redirects to the peripheral consumers of the computer and the compression of the air for the engine. [15], [16]

\section{Abbreviations}

NOMENCLATURE

$\mathrm{N}_{\text {cor: }}$ : speed corrected, $\mathrm{m} / \mathrm{s}$

$\mathrm{N}_{\text {act }}:$ speed actual, $\mathrm{m} / \mathrm{s}$

$\mathrm{N}_{\text {red }}$ : speed reduced, $\mathrm{m} / \mathrm{s}$

$\mathrm{T}_{\text {up }}$ : upstream temperature, $\mathrm{K}$

$\mathrm{T}_{\mathrm{st}}:$ standard temperature, $\mathrm{K}$

$\mathrm{P}_{\text {up }}$ : upstream pressure, $\mathrm{kPa}$

$\mathrm{P}_{\text {st: }}$ standard pressure, $\mathrm{kPa}$

$\dot{m}_{\text {cor: }}$ mass flow rate corrected, -

$\dot{m}_{\text {red }}$ : mass flow rate reduced, - PR: compressor

PR: compressor pressure ratio, -

$A_{0}$ : compressor sound speed ratio, -

$\mathrm{P}_{\text {up }}$ : upstreamabsolute total pressure at port 3 , barA

$P_{\text {out }}$ : downstream absolute total pressure at port 1 , barA

$\mathrm{T}_{\text {up }}$ : upsteam temperature at port $3, \mathrm{~K}$

$\mathrm{T}_{\text {out }}:$ downstream temperature at port $1, \mathrm{~K}$ 
Y: specific heat ratio upstream gas mixture, -

$\eta$ : the isentropic efficiency, -

$\mathrm{P}_{\text {mec }}$ : mechanical power, $\mathrm{W}$

$\omega_{\text {turb }}:$ turbine rotary speed, rad/s

$\mathrm{t}_{\text {turb: }}$ turbine torque, $\mathrm{Nm}$

$\mathrm{P}$ : electrical power, $\mathrm{W}$

$\mathrm{U}$ : voltage, $\mathrm{V}$

I: current, A

R: resistance, $\Omega$

SUBSCRIPTS

rpm : rotations per minute

\section{Declarations}

\subsection{Availability of data and materials}

Not applicable

\subsection{Competing interests}

Not applicable

\subsection{Funding}

Not applicable

\subsection{Authors' contributions}

All the paper scientific information, especially the simulation of the turbocharger with the AMESim software and the experimental data of the turbocharger obtained with the CIMAT test bed!

\subsection{Acknowledgements}

I would like to thank for the cooperation to the company Garrett by Honeywell- turbocharger producers, Company Siemens for the AMESim software, Turbocar Serv SRL for the experimental work and "Transilvania" University of Brasov. 


\section{References}

1. Getzlaff, U., Hensel, S. \& Reichl, S. Simulation of the thermo characteristics of a water-cooled turbocharger. MTZ Worldw 71, 28-31 (2010). https://doi.org/10.1007/BF03227041

2. Chiriac, Rareş, New constructive solutions for hybrid turbochargers- as electrical energy generator for increasing the green supply of the vehicule - Editura Universităţii „Transilvania”, Brașov, România, 2017.

3. Mithun D., An experimental study on the combustion, performane and emission characteristics of a diesel engine, fuelled with diesel-castor oil biodiesel blends, Renewable Energy (2017)

4. Heim K., Existing and future demands on the turbocharging of modern large two-stroke diesel engines. In: 8th Supercharging conference, 1-2 October 2002, Dresden, Germany. Author, F., Author, S.: Title of a proceedings paper. In: Editor, F., Editor, S. (eds.) CONFERENCE 2016, LNCS, vol. 9999, pp. 1-13. Springer, Heidelberg (2016).

5. Scharf, J., Göcmez, T., Wittler, M. et al. Integrating the turbo charging system optimization into the engine development. MTZ Worldw 70, 12-19 (2009). https://doi.org/10.1007/BF03226989

6. Brüstle, C., Wittwer, U., Lester, L., Davis, R.: Neander Dtorque 111, the First Turbodiesel Outboard with Dual Crankshaft Technology. In: 26th Aachen Colloquium Automobile and Engine Technology (2017)

7. Wang, L., Bin, G., Li, X. et al. Effects of unbalance location on dynamic characteristics of high-speed gasoline engine turbocharger with floating ring bearings. Chin. J. Mech. Eng. 29, 271-280 (2016). https://doi.org/10.3901/CJME.2015.1013.121

8. Yang, J., Gao, Y., Liu, Z. et al. A method for modeling and analyzing the rotor dynamics of a locomotive turbocharger. Nonlinear Dyn 84, 287-293 (2016). https://doi.org/10.1007/s11071-015-2497-z

9. Aymanns, R., Scharf, J., Uhlmann, T., Lückmann, D.: A Revision of Quasi Steady Modelling of Turbocharger Turbines in the Simulation of Pulse Charged Engines. Aufladetechnische Konferenz Dresden (2011)

10. Luft, M, Losses of IC engine a chance for electrical energy recuperation, Scientific Journals Scientific Journals, Maritime University of Szczecin Poland - 2012. Seuma

11. Liu, Z.C., Yu, K.B., Tian, J. et al. Influence of rail pressure on a two-stage turbocharged heavy-duty diesel engine under transient operation. Int.J Automot. Technol. 18, 19-29 (2017). https://doi.org/10.1007/s12239-017-0002-z

12. Kellermayr, G., Schutting, E. \& Mitterecker, H. Turbocharging of engines with low cylinder numbers: a thermodynamic consideration. Automot. Engine Technol. 4, 153-167 (2019).

https://doi.org/10.1007/s41104-019-00048-8 
13. LMS AMESim, Ameshelp Library, https://www.siemens.com/plm/support

14. J. Galindo, Strategies for improving the mode transition in a sequential parallel turbocharged automotive diesel engine, International Journal of Automotive Technology 2009;10(2): 141-149

15. Perrot, N., Experimental Study of Centrifugal Compressor Speed Lines Extrapolation for Automotive Turbochargers, 2017, SAE Paper

16. Chiriac, R., New constructive solutions for hybrid turbochargers- as electrical energy generator for increasing the green supply of the vehicule, International Conference for Doctoral Students 2017 (Brasov: "Transilvania" University)

\section{Figures}

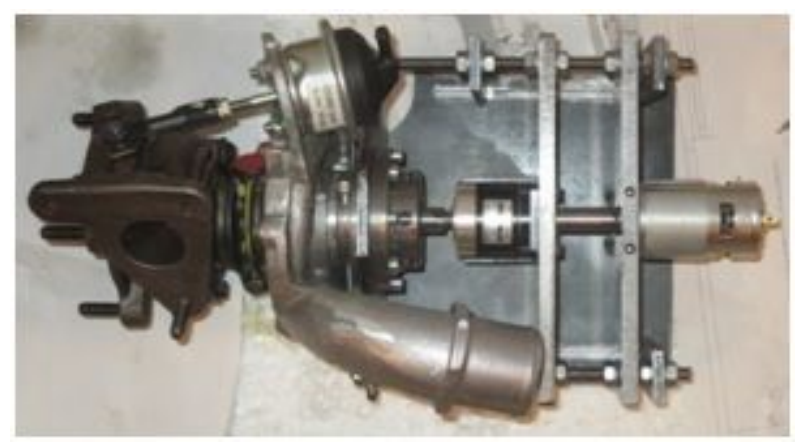

\section{Figure 1}

Real construction of the hybrid turbocharger

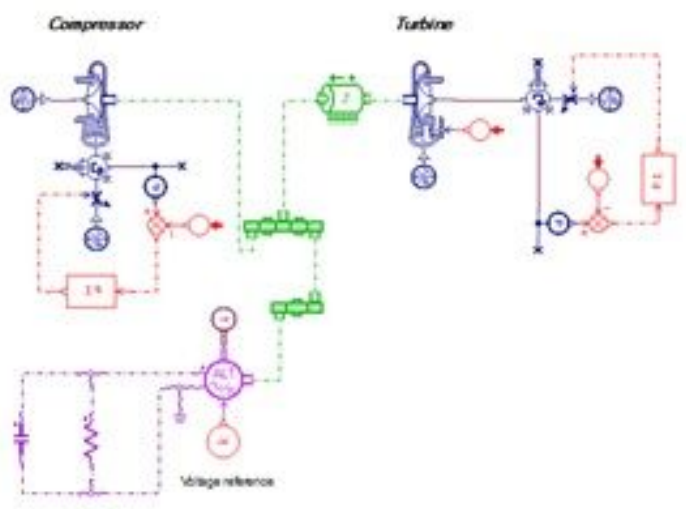

Figure 2

Overview of hybrid turbocharger components with AMESim software 


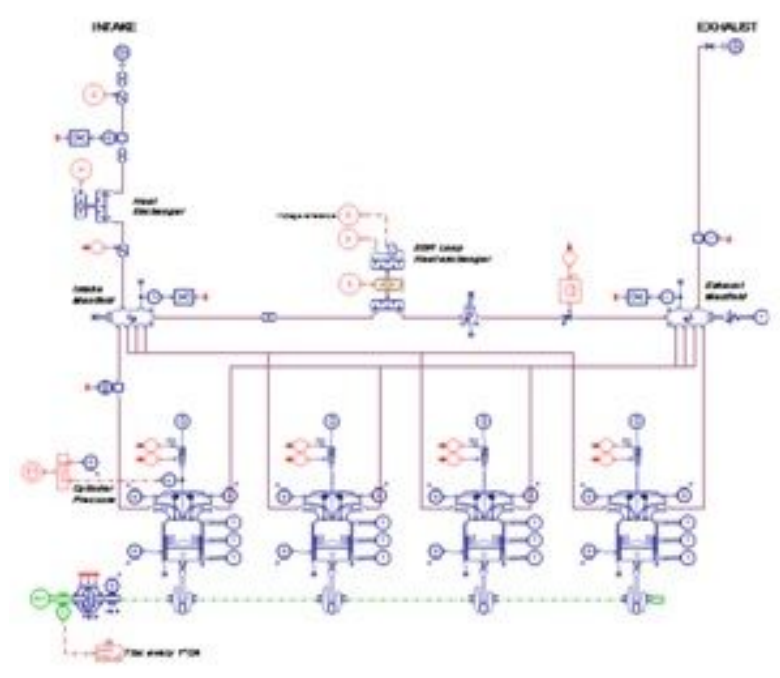

Figure 3

Diesel1.9I naturally aspirated engine simulated with AMESim software

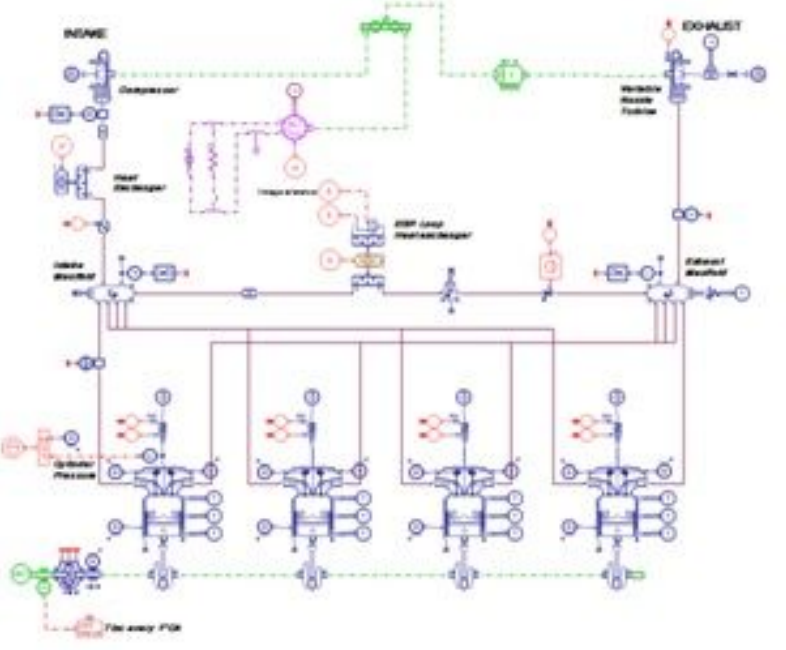

Figure 4

Diesel 1.9 engine equipped with hybrid turbocharger simulated with AMESim

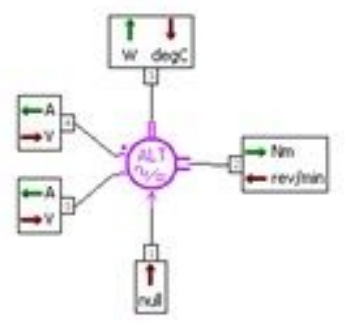

\section{Figure 5}

Alternator symbol and main parameters in AMESim Software 


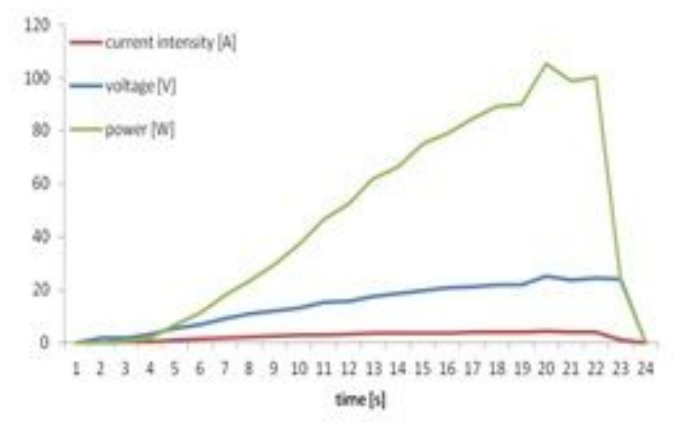

Figure 6

The current intensity, the voltage and the power from the experimental results in relation to time

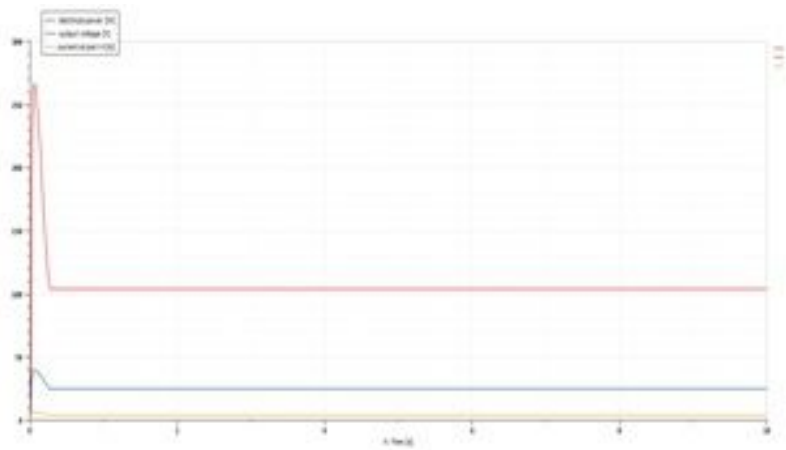

\section{Figure 7}

The current intensity, the voltage and the power from the simulation results in relation to time

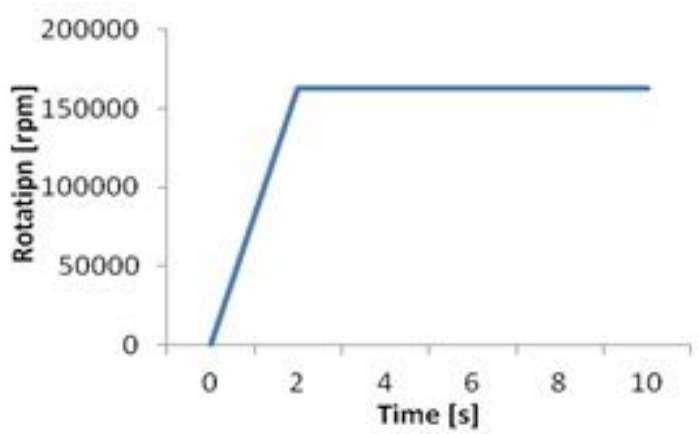

Figure 8

The speed rotor shaft in rotation per minute, rpm from the experimental results in relation to time 


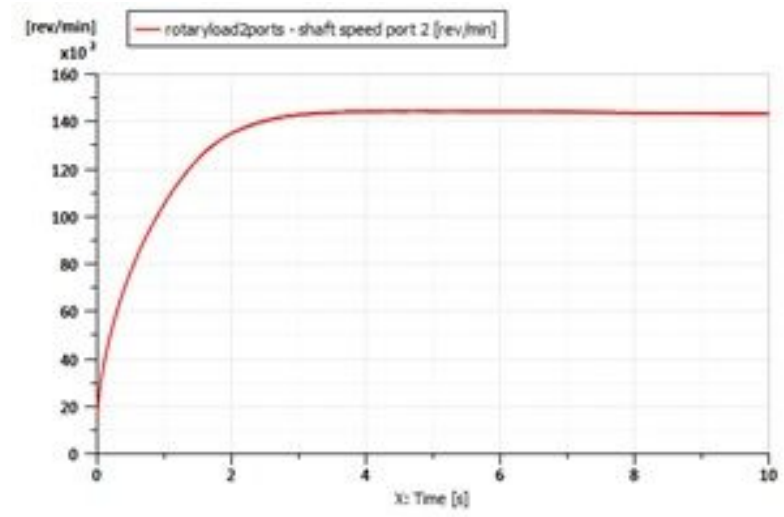

Figure 9

The speed rotor shaft in rotation per minute, rpm simulated with AMESim in relation to time

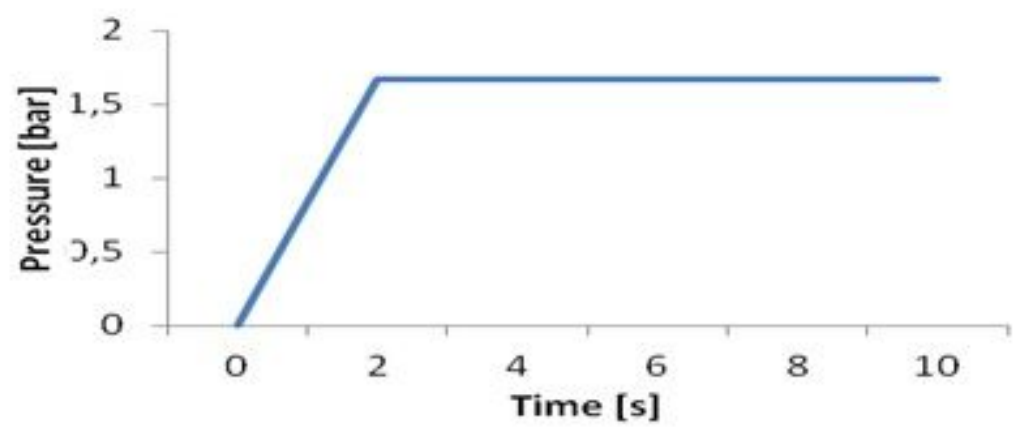

\section{Figure 10}

The compressor outlet pressure from the experimental results in relation to time

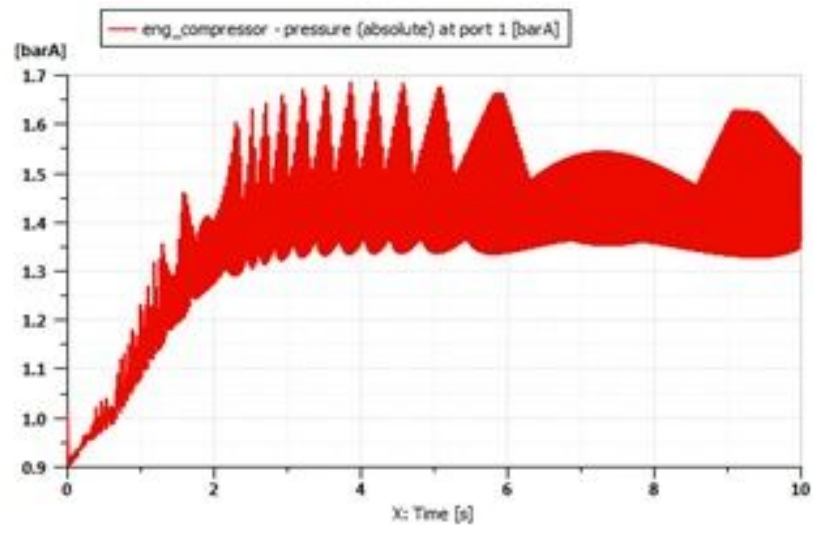

Figure 11

The compressor outlet pressure simulated with AMESim 


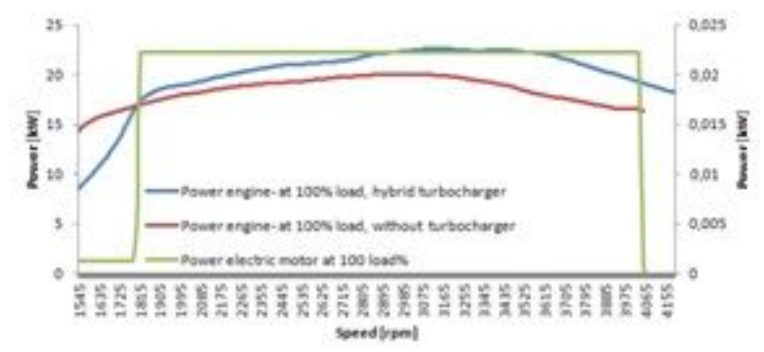

\section{Figure 12}

Comparison between rated power naturally aspirated / turbo hybrid engine and generator load at $100 \%$ load

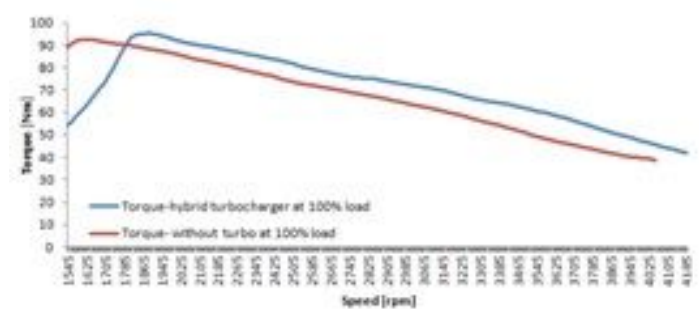

\section{Figure 13}

Comparison between natural naturally aspirated engine and hybrid turbo at $100 \%$ load

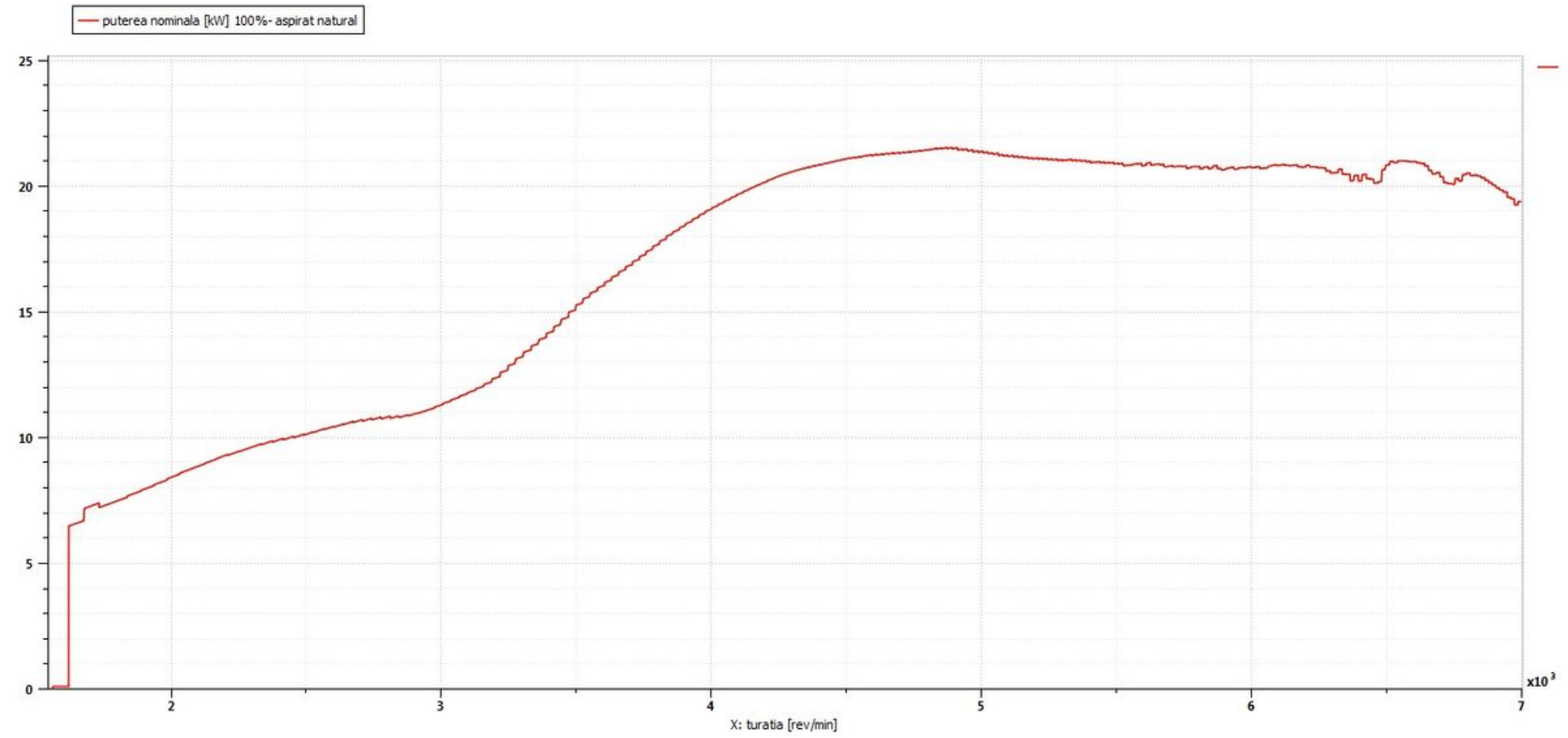

\section{Figure 14}

Rated engine power at $100 \%$ load simulated with AMESim software of naturally aspirated Diesel 1.9 engine 


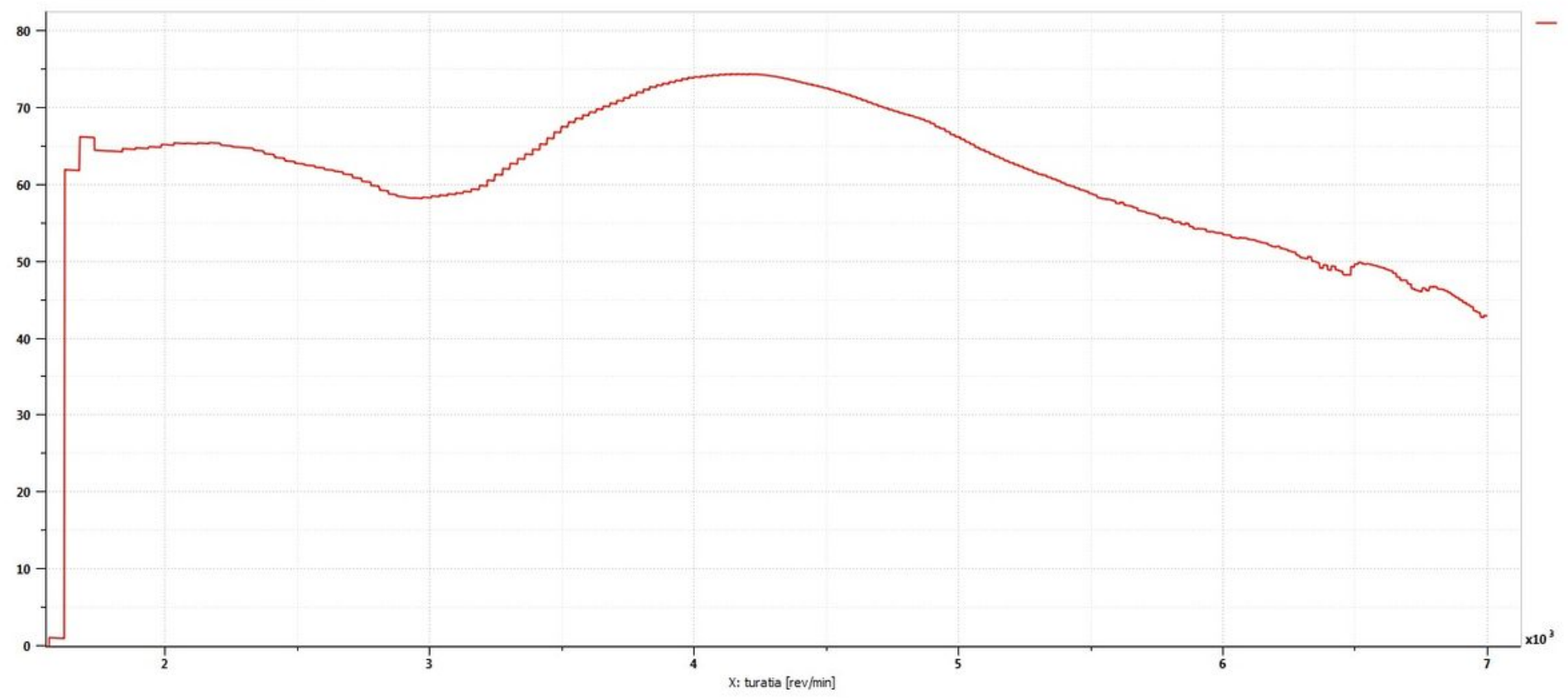

Figure 15

The torque at load $100 \%$ simulated with the AMESim software of the naturally aspirated Diesel 1.9 engine

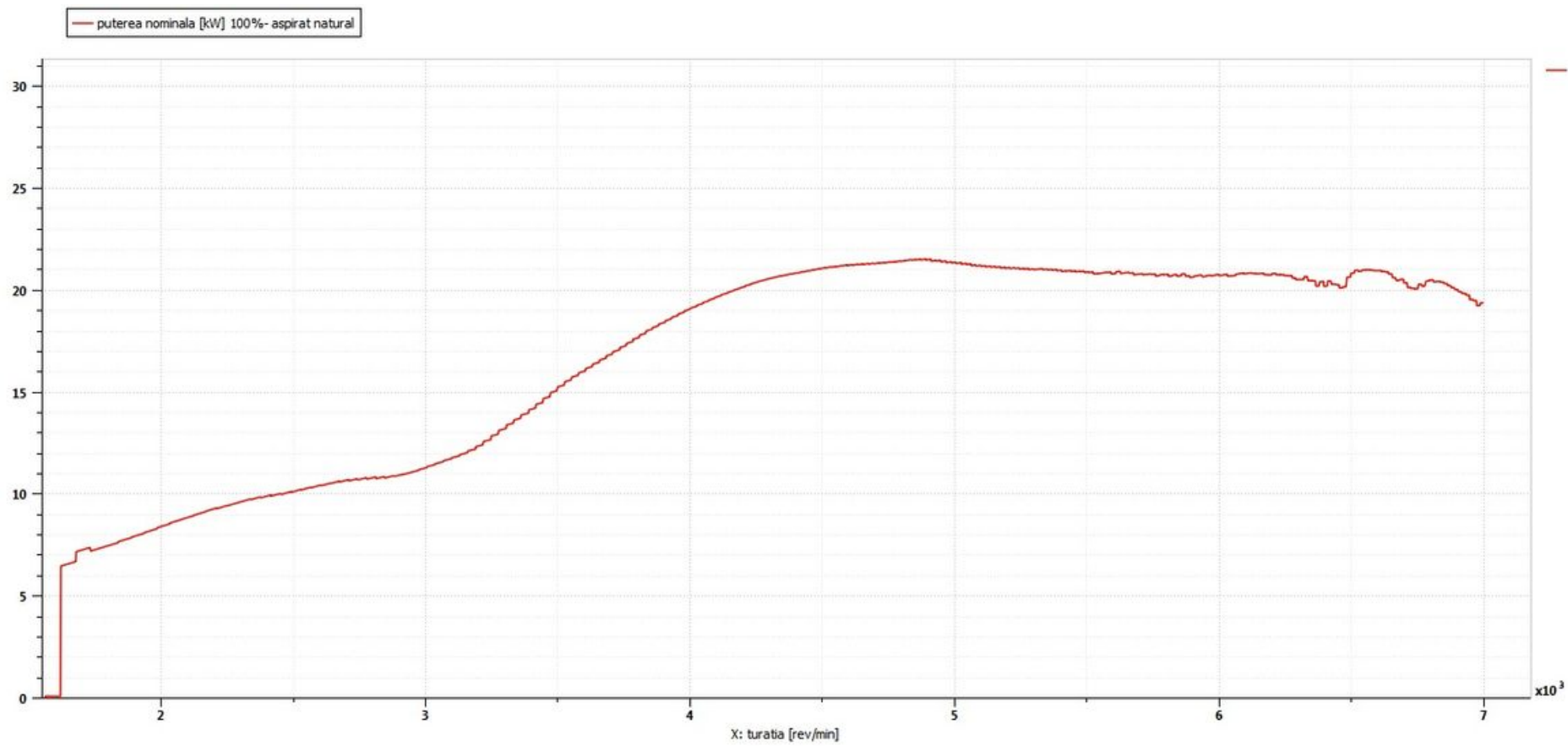

Figure 16

Rated engine power at $100 \%$ load simulated with AMESim software of Diesel 1.9 engine equipped with hybrid turbocharger 


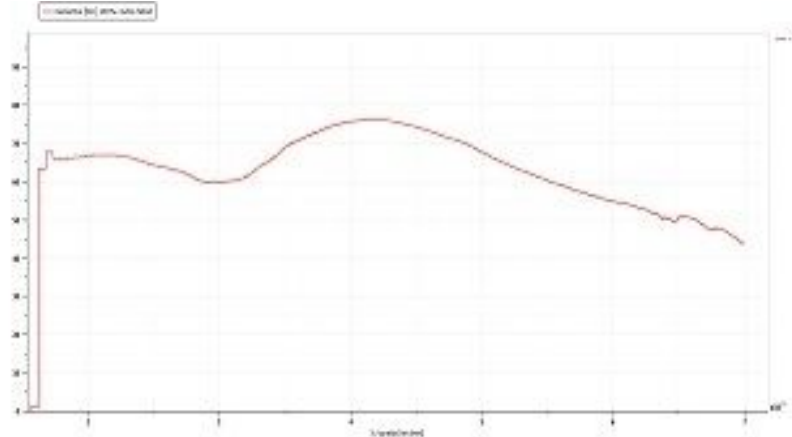

Figure 17

Load torque $100 \%$ simulated with AMESim software of Diesel 1.9 engine equipped with hybrid turbocharger 